\title{
Metabolic syndrome is an independent risk factor for stroke and acute renal failure after coronary artery bypass grafting
}

\author{
Kan Kajimoto, MD, PhD, ${ }^{\mathrm{a}}$ Katsumi Miyauchi, MD, ${ }^{\mathrm{b}}$ Takatoshi Kasai, MD, PhD, ${ }^{\mathrm{b}}$ Naotake Yanagisawa, MB, ${ }^{\mathrm{b}}$

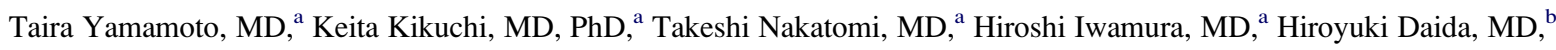 \\ and Atsushi Amano, MD ${ }^{\mathrm{a}}$
}

\begin{abstract}
Objectives: Metabolic syndrome is common among patients having coronary artery bypass grafting. However, it remains unclear whether it has a significant impact on postoperative complications. We aimed to determine whether metabolic syndrome negatively influences the postoperative outcomes of coronary artery bypass grafting.
\end{abstract}

\begin{abstract}
Methods: We enrolled 1183 patients who had coronary artery bypass grafting at Juntendo University Hospital between 1984 and 1992. Patients were categorized by the presence or absence of metabolic syndrome using the modified National Cholesterol Education Program Adult Treatment Panel III definition with body mass index in the place of waist circumference. Multivariate analysis was performed to assess the relationships between preoperative presence of metabolic syndrome and postoperative outcomes.
\end{abstract}

Results: Metabolic syndrome was present in $551(46.6 \%)$ patients and absent in $632(53.4 \%)$. Postoperative stroke occurred in $4.7 \%$ of patients with metabolic syndrome and $2.1 \%$ of patients without metabolic syndrome $(P<.0001)$. Postoperative acute renal failure occurred in $3.8 \%$ of patients with metabolic syndrome and $1.1 \%$ of patients without metabolic syndrome. On multivariate analysis, metabolic syndrome had odds ratios of 2.47 (95\% confidence interval $1.22-4.99 ; P=.012$ ) for postoperative stroke and 3.81 (95\% confidence interval $1.42-10.3 ; P=.008$ ) for postoperative acute renal failure.

Conclusions: This study showed the clinical importance of metabolic syndrome with respect to postoperative stroke and acute renal failure in patients having coronary artery bypass grafting. Like many established risk factors for postoperative complications, metabolic syndrome should be recognized as a novel risk factor for adverse events.

Metabolic syndrome is highly prevalent in patients having coronary artery bypass grafting (CABG). However, a few studies have investigated the relationship between metabolic syndrome and perioperative outcome of CABG. ${ }^{1,2}$ Therefore, the goal of this study was to investigate whether preoperative presence of metabolic syndrome is associated with adverse outcomes after CABG.

\footnotetext{
METHODS

Patients

Preoperative data from patients who had isolated CABG at Juntendo University Hospital between January 1984 and December 1992 were entered into an institutional structured database. This study was performed according to the ethics policies of the institution and was approved by the Internal Review Board. All CABG procedures were performed under conventional cardiopulmonary bypass with crystalloid cardioplegic solution,

From the Departments of Cardiovascular Surgery ${ }^{\mathrm{a}}$ and Cardiology, ${ }^{\mathrm{b}}$ Juntendo University School of Medicine, Tokyo, Japan.

The abstract was presented at the 34th Annual Meeting of the Western Thoracic Surgical Association held at the Sheraton Keauhou Bay Resort, Kona, Hawaii, June 25-28, 2008.

Received for publication June 20, 2008; revisions received Oct 14, 2008; accepted for publication Nov 22, 2008.

Address for reprints: Katsumi Miyauchi, MD, Department of Cardiology, Juntendo University School of Medicine, 2-1-1 Hongo, Bunkyo-ku, Tokyo, Japan (E-mail: ktmmy@med.juntendo.ac.jp).

J Thorac Cardiovasc Surg 2009;137:658-63

$0022-5223 / \$ 36.00$

Copyright (C) 2009 by The American Association for Thoracic Surgery

doi:10.1016/j.jtcvs.2008.11.043
}

moderate systemic hypothermia $\left(28^{\circ} \mathrm{C}-32^{\circ} \mathrm{C}\right)$, topical cardiac cooling, and cardioplegic arrest. Demographic data (including age, gender, and body mass index [BMI]), coronary risk factors (blood pressure on admission; fasting levels of total cholesterol, low-density lipoprotein cholesterol, high-density lipoprotein [HDL] cholesterol, triglycerides, and plasma glucose; smoking history; and family history of coronary artery disease), medication use, and operative parameters were prospectively recorded.

Metabolic syndrome was diagnosed if patients had 3 or more of the following 5 criteria, based on a modified National Cholesterol Education Program Expert Panel on Detection, Evaluation, and Treatment of High Blood Cholesterol in Adults (Adult Treatment Panel III) (NCEP-ATP III) definition $^{3}$ : obesity, defined as BMI $\geq 25 \mathrm{~kg} / \mathrm{m}^{2}$ based on the established Japanese criteria for obesity, ${ }^{4}$ rather than waist circumference as in the NCEP-ATP III definition (waist circumference data were unavailable), triglycerides $\geq 150$ $\mathrm{mg} / \mathrm{dL}$; HDL cholesterol $<40 \mathrm{mg} / \mathrm{dL}$ for men, $<50 \mathrm{mg} / \mathrm{dL}$ for women; blood pressure $\geq 130 / 85 \mathrm{~mm} \mathrm{Hg}$ or treatment with antihypertensive medication; and fasting blood glucose $\geq 100 \mathrm{mg} / \mathrm{dL}$ or treatment with oral hypoglycemics or insulin. Each patient was further categorized based on the presence of coronary risk factors. Diabetes mellitus was defined as fasting plasma glucose levels $\geq 126 \mathrm{mg} / \mathrm{dL}$ or as a requirement for treatment with oral hypoglycemic medication or insulin. Hypertension was defined as a systolic blood pressure $\geq 140 \mathrm{~mm} \mathrm{Hg}$, a diastolic blood pressure $\geq$ $90 \mathrm{~mm} \mathrm{Hg}$, or a requirement for treatment with specific antihypertensive medication. Chronic kidney disease (CKD) was defined as glomerular filtration rate $<60 \mathrm{~mL} \cdot \mathrm{min}^{-1} \cdot 1.73 \mathrm{~m}^{-2}$, as calculated by the Cockcroft-Gault equation, without dialysis treatment. Peripheral artery disease was defined as a history of claudication, previous vascular procedure, or evidence of femoral or abdominal vascular sounds on physical examination.

\section{Outcomes}

The incidences of postoperative adverse outcomes were obtained from our institutional structured database. Postoperative adverse outcomes 


$\begin{array}{ll}\text { Abbreviations and } & \text { Acronyms } \\ \text { ARF } & =\text { acute renal failure } \\ \text { BMI } & \text { body mass index } \\ \text { CABG } & \text { coronary artery bypass grafting } \\ \text { CI } & \text { confidence interval } \\ \text { CKD } & \text { chronic kidney disease } \\ \text { HDL } & \text { high-density lipoprotein } \\ \text { NCEP-ATP III = } & \text { National Cholesterol Education } \\ & \text { Program Expert Panel on } \\ & \text { Detection, Evaluation, and } \\ & \text { Treatment of High Blood } \\ & \text { Cholesterol in Adults } \\ & \text { (Adult Treatment Panel III) } \\ = & \text { odds ratio }\end{array}$

assessed in this study were in-hospital death, stroke, acute renal failure (ARF), myocardial infarction, respiratory insufficiency, mediastinitis, and new onset of atrial fibrillation within the 30 postoperative days. In-hospital death was defined as death in the hospital from any cause. Stroke was defined as a transient or persistent new central neurologic deficit occurring within 24 hours after surgery. ARF was defined as the need for dialysis or as a $\geq 1.0 \mathrm{mg} / \mathrm{dL}$ increase in postoperative serum creatinine relative to baseline in patients not requiring dialysis. Myocardial infarction was defined as new $Q$ waves on the electrocardiogram (transluminal myocardial infarction) or elevated creatine kinase-MB fraction $(>4 \%)$ within 48 hours after surgery. Respiratory insufficiency was defined as the need for postoperative mechanical ventilatory support for longer than 72 hours. Mediastinitis was defined as a deep sternal wound infection associated with fever and sternal wound instability. Atrial fibrillation was defined as the occurrence of any atrial fibrillation during hospitalization for the index surgery. Patients on preoperative dialysis were excluded in the analysis of ARF. Low-output syndrome was defined as the use of inotropic agents or intra-aortic balloon pump support, or both, to maintain a cardiac index of $<2.0 \mathrm{~L} \cdot \mathrm{min}^{-1} \cdot \mathrm{m}^{-2}$.

\section{Statistical Analysis}

In comparing patient characteristics, categorical data were tabulated as frequencies and percentages, and continuous variables are expressed as means \pm standard deviations. These data were analyzed using chi-square test or Student $t$ test. The effect of metabolic syndrome on incidences of postoperative adverse outcomes after CABG was first determined using univariate analysis. Outcomes with $P<.25$ in the univariate analysis were then analyzed using a multivariate logistic model. Covariates with $P<.25$ in the univariate (chi-square) analysis for each outcome were entered into the multivariate analysis. The model was constructed with a backward stepwise method and then was tested with a forward stepwise method. The proportional hazard assumption was checked by including the interaction term between metabolic syndrome and other covariates in this model. Odds ratios (ORs) and confidence intervals (CIs) were then calculated. $P<0.05$ was considered to indicate an independent risk factor and all reported $P$ values are 2 tailed. All statistical analyses were performed using SPSS version 14.0 for Windows (SPSS Inc, Chicago, Ill).

\section{RESULTS}

\section{Patient Characteristics}

Of the 1183 consecutive patients who had isolated CABG during the study period, $551(46.6 \%)$ met the metabolic syndrome criteria at the time of CABG and $632(53.4 \%)$ did not. Comparisons of baseline characteristics and operative variables between the 2 groups are shown in Table 1 . The average age of the study population was 60 years. Most patients having $\mathrm{CABG}$ were nonobese men who were treated with nitrates and had multivessel coronary artery disease with normal left ventricular systolic function. Diabetes was present in $20.9 \%$ of patients at the time of CABG; all of these cases were type 2 diabetes. When compared with the nonmetabolic syndrome group, the metabolic syndrome group had higher proportions of patients with diabetes and greater use of calcium channel blockers and angiotensinconverting enzyme inhibitors for hypertension. Patients with metabolic syndrome were less likely to have CKD $(P=.07)$. In addition, as expected, patients with metabolic syndrome exhibited significantly higher BMI, fasting blood glucose, triglycerides, and blood pressure and lower HDL cholesterol. No differences between the 2 groups were observed for any other characteristics.

\section{Outcomes}

The results of univariate analysis assessing the relationship between metabolic syndrome and incidence of adverse postoperative outcomes are shown in Table 2. The incidence of stroke and ARF was markedly higher in patients with metabolic syndrome than in those without metabolic syndrome. However, there were no differences between the 2 groups in the incidence of other outcomes.

\section{Stroke}

Overall, incidence of stroke was $3.3 \%$. Table 3 shows the characteristics of patients with postoperative stroke and ARF. The predictors of stroke with a $P$ value $<0.25$ were metabolic syndrome, age, left ventricular ejection fraction, history of cerebrovascular accident, CKD, peripheral arterial disease, cardiopulmonary bypass time, and postoperative low-output syndrome. Interestingly, there were no differences between patients with and without stroke in terms of individual components of metabolic syndrome.

The results of multivariate logistic regression analysis are shown in Table 5. The presence of metabolic syndrome was an independent predictor of stroke (OR: $2.47,95 \% \mathrm{CI}$ : $1.22-4.99, P=.012)$. The other independent risk factors for stroke were history of cerebrovascular accident, age, and cardiopulmonary bypass time.

\section{ARF}

The incidence of postoperative ARF was $2.4 \%$ in patients not on preoperative dialysis. A total of 7 variables-metabolic syndrome; older age; male gender; lower left ventricular ejection fraction; history of cerebrovascular event, CKD, hypertension, peripheral arterial disease, and postoperative low output syndrome-were selected by univariate analysis (Table 4) of ARF. 
TABLE 1. Comparison of characteristics based on the presence or absence of metabolic syndrome

\begin{tabular}{|c|c|c|c|}
\hline & Metabolic syndrome $(n=551)$ & No metabolic syndrome $(n=632)$ & $P$ value \\
\hline Age $(y)$, mean \pm SD & $59 \pm 8$ & $59 \pm 9$ & .36 \\
\hline Male $(\%)$ & $460(84)$ & $535(85)$ & .63 \\
\hline Three-vessel disease, $\mathrm{n}(\%)$ & $381(69)$ & $427(68)$ & .57 \\
\hline Left main coronary stenosis $\geq 50 \%, \mathrm{n}(\%)$ & $60(11)$ & $81(13)$ & .32 \\
\hline Unstable angina, $\mathrm{n}(\%)$ & $85(15)$ & $101(16)$ & .81 \\
\hline Previous cardiac surgery, $\mathrm{n}(\%)$ & $5(0.9)$ & $2(0.3)$ & .26 \\
\hline Emergency surgery, $\mathrm{n}(\%)$ & $13(2.3)$ & $18(2.8)$ & .60 \\
\hline Left ventricular ejection fraction $(\%)$, mean $\pm \mathrm{SD}$ & $63.1 \pm 13.5$ & $62.5 \pm 13.6$ & .40 \\
\hline Congestive heart failure, $\mathrm{n}(\%)$ & $3(0.5)$ & $4(0.6)$ & 1.00 \\
\hline Body mass index $\left(\mathrm{kg} / \mathrm{m}^{2}\right)$, mean $\pm \mathrm{SD}$ & $24.4 \pm 2.5$ & $22.7 \pm 2.3$ & $<.0001$ \\
\hline Diabetes mellitus, $\mathrm{n}(\%)$ & $179(33)$ & $95(15)$ & $<.0001$ \\
\hline Fasting blood sugar (mean $\pm \mathrm{SD}$ ) & $116 \pm 34$ & $103 \pm 30$ & $<.0001$ \\
\hline Hypertension, $\mathrm{n}(\%)$ & $210(38)$ & $176(28)$ & $<.0001$ \\
\hline COPD, n (\%) & $1(0.2)$ & $5(0.8)$ & .22 \\
\hline Peripheral vascular disease, n (\%) & $24(4.5)$ & $24(3.8)$ & .66 \\
\hline Cerebral vascular disease, $\mathrm{n}(\%)$ & $35(6.4)$ & $34(5.4)$ & .54 \\
\hline Chronic kidney disease, n (\%) & $170(31)$ & $227(36)$ & .07 \\
\hline Preoperative dialysis, $\mathrm{n}(\%)$ & $12(2.2)$ & $7(1.1)$ & .17 \\
\hline Preoperative IABP, n (\%) & $5(0.9)$ & $7(1.1)$ & .78 \\
\hline Systolic blood pressure $(\mathrm{mm} \mathrm{Hg})$, mean $\pm \mathrm{SD}$ & $132 \pm 18$ & $127 \pm 17$ & $<.0001$ \\
\hline Diastolic blood pressure $(\mathrm{mm} \mathrm{Hg})$, mean $\pm \mathrm{SD}$ & $77 \pm 12$ & $74 \pm 12$ & $<.0001$ \\
\hline $\mathrm{LDL}$ cholesterol $(\mathrm{mg} / \mathrm{dL})$, mean $\pm \mathrm{SD}$ & $148.1 \pm 47.0$ & $152.7 \pm 48.8$ & .101 \\
\hline HDL cholesterol $(\mathrm{mg} / \mathrm{dL})$, mean $\pm \mathrm{SD}$ & $37.6 \pm 10.4$ & $47.2 \pm 13.2$ & $<.0001$ \\
\hline Triglycerides $(\mathrm{mg} / \mathrm{dL})$, mean $\pm \mathrm{SD}$ & $213.0 \pm 112.0$ & $141.9 \pm 95.1$ & $<.0001$ \\
\hline Current smoker, n (\%) & $398(72)$ & $453(72)$ & .84 \\
\hline \multicolumn{4}{|l|}{ Preoperative medications } \\
\hline Nitrates, n (\%) & $510(93)$ & $581(92)$ & .82 \\
\hline ACE inhibitors, $\mathrm{n}(\%)$ & $21(3.8)$ & $15(2.4)$ & .002 \\
\hline Beta blockers, n (\%) & $242(44)$ & $222(35)$ & .02 \\
\hline Calcium antagonists, $\mathrm{n}(\%)$ & $296(54)$ & $200(32)$ & $<.0001$ \\
\hline Aspirin, n (\%) & $214(39)$ & $264(42)$ & .31 \\
\hline Total bypass time $(\mathrm{min})$, mean $\pm \mathrm{SD}$ & $158 \pm 84$ & $159 \pm 57$ & .92 \\
\hline Use of LITA, n (\%) & $285(54)$ & $311(52)$ & .54 \\
\hline Distal anastomoses (mean $\pm \mathrm{SD}$ ) & $2.5 \pm 0.8$ & $2.4 \pm 0.8$ & .50 \\
\hline Reexploration for bleeding, $\mathrm{n}(\%)$ & $10(1.8)$ & $12(1.9)$ & 1.0 \\
\hline Hospital stay $(\mathrm{d})$, mean \pm SD & $26.8 \pm 23.0$ & $28.0 \pm 23.3$ & .38 \\
\hline
\end{tabular}

$A C E$, Angiotensin II converting enzyme; $C O P D$, chronic obstructive pulmonary disease; $H D L$, high-density lipoprotein; $I A B P$, intra-aortic balloon pump; $L D L$, low-density lipoprotein; LITA, left internal thoracic artery; $S D$, standard deviation.

On multivariate logistic regression analysis, the presence of metabolic syndrome was strongly associated with increased incidence of postoperative ARF (OR: 3.81, 95\% CI: $1.42-10.3, P=.008)$. Preoperative CKD, peripheral artery disease, and postoperative low output syndrome were also independent predictors of ARF (Table 5).

\section{DISCUSSION}

Metabolic syndrome has recently received attention as a cluster of cardiovascular disease risk factors comprising insulin resistance, obesity, hypertension, and dyslipidemia. ${ }^{5} \mathrm{It}$ is highly prevalent in patients requiring $\mathrm{CABG}^{1,2}$ and affected $47 \%$ of patients having CABG in this study. The present study demonstrated that the preoperative presence of metabolic syndrome is an independent predictor of postoperative stroke and ARF. Several risk factors for post- operative stroke ${ }^{6-9}$ and $\mathrm{ARF}^{10-12}$ after CABG have been established. In addition, several cohort studies have revealed that metabolic syndrome is associated with increased risk of stroke $^{13}$ and renal dysfunction ${ }^{14-16}$ in the general population. However, the impact of preoperative metabolic syndrome in terms of post-CABG complications has been less documented. The present study is a large observational report aiming to evaluate the relationship between metabolic syndrome and postoperative adverse outcomes following CABG.

Increased numbers of high-risk patients requiring $\mathrm{CABG}$ results in greater prevalence of comorbidities and complications following CABG. The prevalence of metabolic syndrome is also increasing, ${ }^{17}$ and this would be expected to elevate morbidity among patients requiring CABG. We therefore hypothesized that metabolic syndrome would 
TABLE 2. Comparison of in-hospital outcomes based on the presence or absence of metabolic syndrome

\begin{tabular}{lccc}
\hline & $\begin{array}{c}\text { Metabolic } \\
\text { syndrome }\end{array}$ & $\begin{array}{c}\text { No metabolic } \\
\text { syndrome }\end{array}$ & $\begin{array}{c}\boldsymbol{P} \\
\text { value }\end{array}$ \\
\hline In-hospital death (\%) & 1.5 & 0.9 & .44 \\
Stroke (\%) & 4.7 & 2.1 & .014 \\
Acute renal failure (\%) & $3.9 *$ & $1.1 *$ & .003 \\
Myocardial infarction (\%) & 2.7 & 3.5 & .51 \\
Respiratory insufficiency (\%) & 22 & 21 & .57 \\
Mediastinitis (\%) & 2.2 & 1.1 & .49 \\
New onset of atrial fibrillation (\%) & 16 & 13 & .32 \\
\hline
\end{tabular}

*Patients on preoperative dialysis were excluded.

have a considerable negative impact in patients following CABG.

The incidence of stroke following CABG is reported to be as high as $1 \%$ to $6 \%$, and its mortality rate is $25 \%{ }^{6}$ Postoperative stroke is an expensive and severe complication of CABG with prolongation of hospital stay ${ }^{6-9}$ and poor prognosis.

Although metabolic syndrome patients have increased prevalence of conventional risk factors for postoperative stroke, metabolic syndrome might also increase the risk of postoperative stroke in other ways. The essential etiologic mechanism of metabolic syndrome is accepted to be insulin resistance, which is an independent risk factor for cardiovascular disease and causes endothelial dysfunction with tendencies toward thrombosis and inflammation. ${ }^{3}$ Endothelial dysfunction is the first step in atherosclerosis and might potentially contribute to the development of cerebrovascular disease. In addition, prothrombotic status promotes cardiovascular disease. Patients with metabolic syndrome exhibit elevation of coagulation factors, including fibrinogen, von Willebrand factor, plasminogen activator inhibitor-1, factor VIII, and tissue plasminogen activator. ${ }^{3}$ Elevated fibrinogen level is an independent risk factor for cardiovascular disease, and increased levels of von Willebrand factor are reported to be associated with occurrence of ischemic stroke in the general population. ${ }^{18}$ Moreover, the preoperative presence of certain specific genetic polymorphisms for interleukin-6 and C-reactive protein is strongly related to the incidence of postoperative stroke. ${ }^{19}$ This supports the notion that preoperative tendency toward inflammation is associated with postoperative stroke. In patients with metabolic syndrome, this proinflammatory tendency, including elevated cytokines (tumor necrotic factor-alpha and interleukin-6) and C-reactive protein, ${ }^{3}$ might also contribute to the development of postoperative stroke.

Several epidemiologic studies have examined the association between metabolic syndrome and risk of stroke in the general population. Among 10,357 participants in the Third National Health and Nutrition Examination Survey, metabolic syndrome, as defined by NCEP-ATP III criteria, was associated with a 2.2-fold increased prevalence of stroke. ${ }^{20}$
TABLE 3. Characteristics of patients with postoperative stroke

\begin{tabular}{|c|c|c|c|}
\hline & $\begin{array}{c}\text { Stroke } \\
(\mathbf{n}=\mathbf{3 9})\end{array}$ & $\begin{array}{l}\text { No stroke } \\
(n=1144)\end{array}$ & $\begin{array}{c}P \\
\text { value }\end{array}$ \\
\hline Metabolic syndrome $(\%)^{*}$ & 67 & 46 & .014 \\
\hline $\begin{array}{l}\text { Serum HDL cholesterol } \\
\text { levels }<40 \mathrm{mg} / \mathrm{dL} \text { for } \\
\text { men, }<50 \mathrm{mg} / \mathrm{dL} \text { for } \\
\text { women }(\%)\end{array}$ & 59 & 47 & .14 \\
\hline $\begin{array}{l}\text { Serum triglyceride } \\
\quad \text { levels } \geq 150 \mathrm{mg} / \mathrm{dL}(\%)\end{array}$ & 56 & 51 & .52 \\
\hline $\begin{array}{l}\text { Fasting blood sugar } \geq 100 \\
\text { mg/dL }(\%) \dagger\end{array}$ & 56 & 51 & .52 \\
\hline $\begin{array}{l}\text { Blood pressure } \geq 130 / \\
\quad 85 \mathrm{~mm} \mathrm{Hg}(\%) \ddagger\end{array}$ & 77 & 71 & .47 \\
\hline $\begin{array}{l}\text { Body mass } \\
\quad \text { index } \geq 25 \mathrm{~kg} / \mathrm{m}^{2}(\%)\end{array}$ & 28 & 27 & .56 \\
\hline Age $(\text { mean } \pm \mathrm{SD})^{*}$ & $63 \pm 7$ & $59 \pm 9$ & $<.0001$ \\
\hline Gender, male $(\%)$ & 87 & 84 & .82 \\
\hline $\begin{array}{l}\text { Left ventricular ejection } \\
\quad \text { fraction }(\text { mean } \pm \mathrm{SD})^{*}\end{array}$ & $59 \pm 16$ & $62 \pm 13$ & .15 \\
\hline $\begin{array}{l}\text { History of cerebrovascular } \\
\text { accident }(\%)^{*}\end{array}$ & 33 & 4.9 & $<.0001$ \\
\hline $\begin{array}{l}\text { Chronic kidney } \\
\text { disease }(\%)^{*}\end{array}$ & 13 & 5.7 & .075 \\
\hline Diabetes mellitus (\%) & 26 & 23 & .70 \\
\hline Hypertension (\%) & 38 & 32 & .49 \\
\hline $\begin{array}{l}\text { Peripheral arterial } \\
\text { disease }(\%)\end{array}$ & 10 & 3.8 & .069 \\
\hline $\begin{array}{l}\text { Acute coronary } \\
\text { syndrome }(\%)\end{array}$ & 21 & 16 & .38 \\
\hline $\begin{array}{l}\text { Cardiopulmonary bypass } \\
\text { time (min) }\end{array}$ & $168 \pm 57$ & $159 \pm 71$ & .35 \\
\hline $\begin{array}{l}\text { Aortic crossclamp } \\
\text { time }(\mathrm{min})\end{array}$ & $89 \pm 32$ & $88 \pm 33$ & .99 \\
\hline $\begin{array}{l}\text { Postoperative atrial } \\
\text { fibrillation }(\%)\end{array}$ & 10 & 15 & .64 \\
\hline $\begin{array}{l}\text { Postoperative low output } \\
\text { syndrome }(\%)^{*}\end{array}$ & 7.7 & 3.1 & .13 \\
\hline
\end{tabular}

$H D L$, High-density lipoprotein; $S D$, standard deviation. *Variables selected into the multivariate analysis because $P<.25$ other than components of metabolic syndrome $\dagger$ Patients with normal blood pressure receiving treatment with antihypertensive medication were included. †Patients with normal fasting blood glucose levels treated with oral hypoglycemics or insulin were included.

A prospective study of 3298 stroke-free community residents with a 6.4-year follow-up period yielded similar results; in multivariate Cox proportional-hazard models, metabolic syndrome was associated with increased hazard of stroke (hazard ratio 1.5). ${ }^{21}$ These findings could be explained by the fact that intracranial atherosclerosis is associated with lower levels of adiponectin, a protein secreted by adipose cells, in patients with metabolic syndrome; these reduced levels of adiponectin might be linked to ischemic stroke in patients with metabolic syndrome. ${ }^{18}$ These findings support the present finding that metabolic syndrome increases the risk of postoperative stroke.

In addition, the present study suggests that the individual components of metabolic syndrome are not associated with 
TABLE 4. Characteristics of patients with postoperative acute renal failure

\begin{tabular}{|c|c|c|c|}
\hline & $\begin{array}{c}\text { ARF } \\
(n=28)\end{array}$ & $\begin{array}{c}\text { No ARF } \\
(n=1164)\end{array}$ & $\begin{array}{c}P \\
\text { value }\end{array}$ \\
\hline Metabolic syndrome $(\%)^{*}$ & 75 & 45 & .003 \\
\hline $\begin{array}{l}\text { Serum HDL cholesterol } \\
\text { levels }<40 \mathrm{mg} / \mathrm{dL} \text { for men, } \\
\quad<50 \mathrm{mg} / \mathrm{dL} \text { for women }(\%)\end{array}$ & 57 & 46 & .34 \\
\hline $\begin{array}{l}\text { Serum triglyceride } \\
\quad \text { levels } \geq 150 \mathrm{mg} / \mathrm{dL}(\%)\end{array}$ & 71 & 50 & .035 \\
\hline $\begin{array}{l}\text { Fasting blood sugar } \geq 100 \\
\quad \mathrm{mg} / \mathrm{dL}(\%) \dagger\end{array}$ & 43 & 50 & .45 \\
\hline $\begin{array}{l}\text { Blood pressure } \geq 130 / 85 \\
\mathrm{~mm} \mathrm{Hg}(\%) \ddagger\end{array}$ & 89 & 69 & .034 \\
\hline $\begin{array}{l}\text { Body mass index } \geq 25 \\
\mathrm{~kg} / \mathrm{m}^{2}(\%)\end{array}$ & 43 & 23 & .024 \\
\hline Age $($ mean $\pm \mathrm{SD}) *$ & $63 \pm 8$ & $59 \pm 8$ & .008 \\
\hline Gender, male $(\%)^{*}$ & 75 & 83 & .19 \\
\hline $\begin{array}{l}\text { Left ventricular ejection } \\
\text { fraction }(\text { mean } \pm \mathrm{SD})^{*}\end{array}$ & $58 \pm 13$ & $63 \pm 14$ & .073 \\
\hline $\begin{array}{l}\text { History of cerebrovascular } \\
\text { accident }(\%)^{*}\end{array}$ & 11 & 5.3 & .20 \\
\hline Chronic kidney disease $(\%)^{*}$ & 68 & 31 & $<.000$ \\
\hline Diabetes mellitus (\%) & 21 & 23 & 1.0 \\
\hline Hypertension $(\%)^{*}$ & 43 & 32 & .23 \\
\hline Peripheral arterial disease $(\%) *$ & 18 & 3.5 & .003 \\
\hline Acute coronary syndrome $(\%)$ & 21 & 16 & .43 \\
\hline $\begin{array}{l}\text { Cardiopulmonary bypass } \\
\text { time (min) }\end{array}$ & $169 \pm 57$ & $158 \pm 71$ & .33 \\
\hline Aortic crossclamp time (min) & $92 \pm 33$ & $89 \pm 32$ & .54 \\
\hline $\begin{array}{c}\text { Postoperative atrial } \\
\text { fibrillation (\%) }\end{array}$ & 18 & 14 & .58 \\
\hline $\begin{array}{l}\text { Postoperative low output } \\
\text { syndrome }(\%)^{*}\end{array}$ & 18 & 2 & .002 \\
\hline
\end{tabular}

$A R F$, Acute renal failure; $H D L$, high-density lipoprotein; $S D$, standard deviation *Variables selected into the multivariate analysis because $P<.25$ other than components of metabolic syndrome. †Patients with normal blood pressure receiving treatment with antihypertensive medication were included. ‡Patients with normal fasting blood glucose levels treated with oral hypoglycemics or insulin were included.

postoperative stroke. Metabolic syndrome should therefore be recognized as a novel and important risk factor for postoperative stroke, independent of its individual components.

Postoperative ARF is another life-threatening complication of CABG. The incidence of ARF following cardiac surgery ranges from $1 \%$ to $30 \%$ and its mortality rate was reported to be $15 \%$ to $30 \%{ }^{10-12}$ The risk factors of postoperative ARF include preoperative renal dysfunction, age, presence of peripheral artery disease, and poor left ventricular systolic function. ${ }^{10-12}$ However, the present study found no differences in incidence of each of these risk factors between patients with and without metabolic syndrome. Instead we found that metabolic syndrome independently increases the risk of postoperative ARF in patients having CABG.

Insulin resistance and hyperinsulinemia, considered fundamental pathogenic factors in metabolic syndrome, are
TABLE 5. Results of multivariate analysis of risk factors for postoperative stroke and acute renal failure

\begin{tabular}{lcc}
\hline & OR $(\mathbf{9 5} \% \mathbf{C I})$ & $\boldsymbol{P}$ value \\
\hline Stroke & & \\
$\quad$ Metabolic syndrome & $2.47(1.22-4.99)$ & .012 \\
History of cerebrovascular incidents & $9.52(4.50-20.2)$ & $<.0001$ \\
Age & $1.08(1.03-1.13)$ & .001 \\
Cardiopulmonary bypass time & $1.01(1.00-1.01)$ & .024 \\
Acute renal failure & & \\
$\quad$ Metabolic syndrome & $3.81(1.42-10.3)$ & .008 \\
Chronic kidney disease & $16.0(6.45-39.8)$ & $<.0001$ \\
Peripheral artery disease & $4.85(1.49-15.8)$ & .009 \\
Postoperative low output syndrome & $5.99(1.60-22.4)$ & .008 \\
\hline$O R$, Odds ratio; $C I$, confidence interval. & &
\end{tabular}

reported to directly affect renal function by worsening renal hemodynamics through multiple mechanisms including sodium retention, activation of the sympathetic nervous system, decreased $\mathrm{Na}^{+}, \mathrm{K}^{+}$-ATPase activity, and elevation of glomerular filtration fraction. ${ }^{14}$ These mechanisms could explain the present association of metabolic syndrome and postoperative ARF.

Several epidemiologic studies have revealed the relationship between metabolic syndrome and incidence of CKD in the general population. The Hisayama Study examined risk of CKD conferred by metabolic syndrome in 1440 Japanese subjects ${ }^{14}$; in multivariate analysis, metabolic syndrome was an independent risk factor for CKD (hazard ratio 2.08). The Third National Health and Nutrition Examination Survey showed that metabolic syndrome was associated with a 2.6-fold increased risk of CKD. ${ }^{15}$ In a prospective cohort study, patients with metabolic syndrome had a 1.4-fold greater risk of CKD when compared with those without metabolic syndrome.

Although the detailed mechanisms underlying the strong association between preoperative presence of metabolic syndrome and postoperative incidence of ARF after CABG are unclear, the above findings in the general population support the results of this study.

Pimenta and colleagues ${ }^{22}$ documented that the preoperative presence of metabolic syndrome was not related to the in-hospital adverse outcomes in 107 patients having CABG. However, the present study assessed a larger sample, and the impact of metabolic syndrome was evaluated more thoroughly. In addition, Echahidi and associates ${ }^{1,2}$ recently reported that the preoperative presence of metabolic syndrome is associated with postoperative mortality and new onset of atrial fibrillation after CABG. Although we did not find increased mortality or new-onset atrial fibrillation associated with metabolic syndrome, the present study determined that the presence of metabolic syndrome increased the risk of other postoperative complications, namely stroke and ARF, after CABG.

Interestingly, Dennis and colleagues ${ }^{23}$ documented the impact of the "deadly quartet," which was a clustering of 
cardiovascular risks before the concept of metabolic syndrome was established, in 6428 patients having CABG. They reported that the presence of the deadly quartet was associated with postoperative midterm mortality. We also recently reported that metabolic syndrome was an increased risk for long-term mortality after $\mathrm{CABG} .{ }^{24}$ Thus, the presence of metabolic syndrome has a large impact on adverse outcomes, not only immediately after surgery, but also over the long term.

This study has several limitations. It was a post hoc investigation and did not address in detail the etiologic mechanisms of stroke. Moreover, treatment in this study differed in some respects from that in current use-for instance, cardiopulmonary bypass is not currently used in all cases of $\mathrm{CABG}$, with arterial grafts being more prevalent, and perioperative medications and eligibility for surgical revascularization have changed. Moreover, we did not address intra- and postoperative serum glucose levels in this study. The present study identified obesity on the basis of BMI, as waist circumference measurements were not available. However, studies have demonstrated concordance between a diagnosis of metabolic syndrome based on BMI and that based on waist circumference. ${ }^{25,26}$ We selected a BMI $\geq 25 \mathrm{~kg} / \mathrm{m}^{2}$ as the cutoff point for obesity based on the results of a previous study on the relationship between BMI, visceral fat area, waist circumference, and obesity in a Japanese population. ${ }^{4}$ If waist circumstance had been used to define obesity in the detection of metabolic syndrome, more specific results might have been obtained. This study is also limited by a lack of data on the progression of each risk factor in metabolic syndrome. Moreover, patients were racially homogeneous (almost all were Japanese), and all were treated at the same institution.

In conclusion, this study represents a large-scale evaluation of the relationship between metabolic syndrome and postoperative outcomes after CABG. It demonstrated that metabolic syndrome predicted an increased incidence of postoperative stroke and ARF. Our findings suggest that components of metabolic syndrome should be treated aggressively, even though they may be mild risk factors when considered individually. We should recognize metabolic syndrome as a novel risk factor for postoperative stroke and ARF, similar to other established risk factors for postoperative complications.

\section{References}

1. Echahidi N, Pibarot P, Després JP, Daigle JM, Mohty D, Voisine P, et al. Metabolic syndrome increases operative mortality in patients undergoing coronary artery bypass grafting surgery. J Am Coll Cardiol. 2007;50:843-51.

2. Echahidi N, Mohty D, Pibarot P, Després JP, O'Hara G, Champagne J, et al. Obesity and metabolic syndrome are independent risk factors for atrial fibrillation after coronary artery bypass graft surgery. Circulation. 2007;116:I213-9.

3. Grundy SM, Cleeman JI, Daniels SR, Donato KA, Eckel RH, Franklin BA, et al. American Heart Association; National Heart, Lung, and Blood Institute. Diagnosis and management of the metabolic syndrome: an American Heart Association/ National Heart, Lung, and Blood Institute Scientific Statement. Circulation. 2005; 112:2735-52.
4. Examination Committee of Criteria for. Obesity Disease"' in Japan. Japan Society for the Study of Obesity: New criteria for "obesity disease" in Japan. Circ J. 2002;66:987-92.

5. Eckel RH, Grundy SM, Zimmet PZ. The metabolic syndrome. Lancet. 2005;365: 1415-28.

6. John R, Choudhri AF, Weinberg AD, Ting W, Rose EA, Smith CR, et al. Multicenter review of preoperative risk factors for stroke after coronary artery bypass grafting. Ann Thorac Surg. 2000;69:30-5.

7. Likosky DS, Leavitt BJ, Marrin CA, Malenka DJ, Reeves AG, Weintraub RM, et al. Northern New England Cardiovascular Disease Study Group. Intra- and postoperative predictors of stroke after coronary artery bypass grafting. Ann Thorac Surg. 2003;76:428-34.

8. Ozatik MA, Göl MK, Fansa I, Uncu H, Küçüker SA, Küçükaksu S, et al. Risk factors for stroke following coronary artery bypass operations. J Card Surg. 2005;20:52-7.

9. McKhann GM, Grega MA, Borowicz LM Jr, Baumgartner WA, Selnes OA. Stroke and encephalopathy after cardiac surgery: an update. Stroke. 2006;37:562-71.

10. Suen WS, Mok CK, Chiu SW, Cheung KL, Lee WT, Cheung D, et al. Risk factors for development of acute renal failure (ARF) requiring dialysis in patients undergoing cardiac surgery. Angiology. 1998;49:789-800.

11. Conlon PJ, Stafford-Smith M, White WD, Newman MF, King S, Winn MP, et al. Acute renal failure following cardiac surgery. Nephrol Dial Transplant. 1999;14: 1158-62.

12. Palomba H, de Castro I, Neto AL, Lage S, Yu L. Acute kidney injury prediction following elective cardiac surgery: AKICS Score. Kidney Int. 2007;72:624-31.

13. Li W, Ma D, Liu M, Liu H, Feng S, Hao Z, et al. Association between metabolic syndrome and risk of stroke: a meta-analysis of cohort studies. Cerebrovasc Dis. 2008;25:539-47.

14. Ninomiya T, Kiyohara Y, Kubo M, Yonemoto K, Tanizaki Y, Doi Y, et al. Metabolic syndrome and CKD in a general Japanese population: the Hisayama Study. Am J Kidney Dis. 2006;48:383-91.

15. Chen J, Muntner P, Hamm LL, Jones DW, Batuman V, Fonseca V, et al. The metabolic syndrome and chronic kidney disease in U.S. adults. Ann Intern Med. 2004; 140:167-74

16. Kurella M, Lo JC, Chertow GM. Metabolic syndrome and the risk for chronic kidney disease among nondiabetic adults. J Am Soc Nephrol. 2005;16:2134-40.

17. Expert Panel on Detection, Evaluation, and Treatment of High Blood Cholesterol in Adults. Executive Summary of the Third Report of the National Cholesterol Education Program (NCEP) Expert Panel on Detection, Evaluation, and Treatment of High Blood Cholesterol in Adults (Adult Treatment Panel III). JAMA. 2001;285:2486-97.

18. Bongers TN, de Maat MP, van Goor ML, Bhagwanbali V, van Vliet HH, Gómez García EB, et al. High von Willebrand factor levels increase the risk of first ischemic stroke: influence of ADAMTS13, inflammation, and genetic variability. Stroke. 2006;37:2672-7.

19. Grocott HP, White WD, Morris RW, Podgoreanu MV, Mathew JP, Nielsen DM, et al. Perioperative Genetics and Safety Outcomes Study (PEGASUS) Investigative Team. Genetic polymorphisms and the risk of stroke after cardiac surgery. Stroke. 2005;36:1854-8.

20. Muntner P, He J, Chen J, Fonseca V, Whelton PK. Prevalence of non-traditional cardiovascular disease risk factors among persons with impaired fasting glucose, impaired glucose tolerance, diabetes, and the metabolic syndrome: analysis of the Third National Health and Nutrition Examination Survey (NHANES III). Ann Epidemiol. 2004; 14:686-95.

21. Boden-Albala B, Sacco RL, Lee HS, Grahame-Clarke C, Rundek T, Elkind MV et al. Metabolic syndrome and ischemic stroke risk: Northern Manhattan Study. Stroke. 2008;39:30-5.

22. Pimenta E, Passarelli O Jr, Borelli F, Sousa MG, Gun C, Amato V, et al. Metabolic syndrome in patients undergoing coronary artery bypass graft: prevalence and a marker of morbidity/mortality during hospitalization and 30 days after hospital discharge. Arq Bras Cardiol. 2007;88:413-7.

23. Sprecher DL, Pearce GL. How deadly is the "deadly quartet"? A post-CABG evaluation. J Am Coll Cardiol. 2000;36:1159-65.

24. Kajimoto K, Kasai T, Miyauchi K, Hirose H, Yanagisawa N, Yamamoto T, et al Metabolic syndrome predicts 10-year mortality in non-diabetic patients following coronary artery bypass surgery. Circ J. 2008;72:1481-6.

25. Ford ES, Giles WH, Dietz WH. Prevalence of the metabolic syndrome among US adults. JAMA. 2002;287:356-9.

26. Park YW, Zhu S, Palaniappan L, Heshka S, Carnethon MR, Heymsfield SB. The metabolic syndrome: prevalence and associated risk factor findings in the US population from the Third National Health and Nutrition Examination Survey, 1988-1994. Arch Intern Med. 2003;163:427-36. 